\title{
Bottom Ash of the Largest Kuzbass Coal Power Plants: Secondary Use Possibility
}

\author{
Aleksey Kargin ${ }^{1 *}$, and Nikolay Mashkin ${ }^{2}$ \\ ${ }^{1}$ T.F. Gorbachev Kuzbass State Technical University, Str. Vesennyaya 28, Kemerovo, Russia, 650000 \\ ${ }^{2}$ Novosibirsk State Technical University, 20 Prospect K. Marksa, Novosibirsk, Russia, 630073
}

\begin{abstract}
Kemerovo district coal power plant, Tom-Usinskaya district coal power plant and Belovo district coal power plant are the largest coal power plants in Kuzbass and during the combustion of coal they generate annually about 1600 tons of coal ash which consists of fly ash and bottom ash. Almost all the generated ash is disposed into ash dumps except a small quantity of fly ash $(3.5 \%)$ that is effectively utilized. Therefore, secondary use of the bottom ash can be a sustainable solution for reducing its byproducts and overcoming the scarcity of raw materials required for construction work. Therefore, the main aim of this research was to determine the chemical composition and granulometric properties of bottom ash to find out the possibility of using it as raw material for the building materials production. A series of laboratory experiments were conducted to determine basicity index, activity index, average grain density, bulk density, true density and grain size distribution. The experimental results reveal that the particle size of ash is predominantly sand-sized while containing some silt-sized and rubble-sized fractions as well. The studied bottom ash has a low basicity and activity index, respectively, does not have independent hydraulic activity. Thus, bottom ash of the largest Kuzbass coal power plants can be used as raw material for the building materials production.
\end{abstract}

\section{Introduction}

The Russian power industry annually produces not only heat and electricity, but also more than 25 million tons of ash and slag waste [1]. Ash dumps occupy large areas of valuable urban or suburban land and degrade the environment. The ash and slag waste dumps area are located is more than 20000 hectares today. On the other hand, vast experience of ash and slag secondary use has accumulated in the in the world. Countries such as England and Germany use the whole annual volume of ash and slag waste, China more than $80 \%$, Poland - up to $80 \%$, the USA - about 70\% [2]. Unfortunately, Russia lags behind the listed countries by ash and slag processing volume.

Kemerovo region is the one of the leading regions in the concentration of the coal power plants and at the same time in the volume of ash and slag waste. The large amount of coal deposits contributes high prevalence of power plants working on solid fuels. The

\footnotetext{
${ }^{*}$ Corresponding author: karginaa@kuzstu.ru
} 
Kuzbass coal power plants scattered throughout the region. Kemerovo district coal power plant, Tom-Usinskaya district coal power plant and Belovo district coal power plant are the largest coal power plants in Kuzbass. They are respectively located in the north, south and center of the region (Fig. 1).

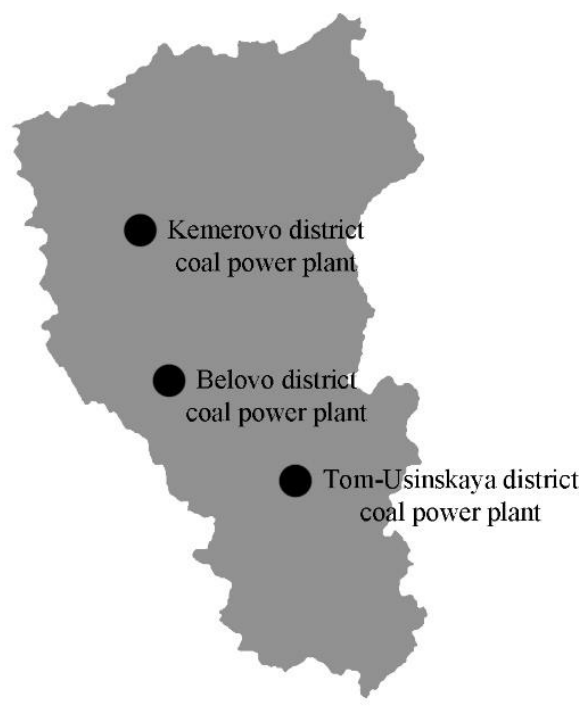

Fig. 1. Location of the largest Kuzbass coal power plants.

They are annually generates about 1600 tons of coal ash which consists of fly ash and bottom ash. Most of bottom ash is disposed into ash dumps. Almost all the generated fly ash is effectively utilized. But it is only a small part of the all generated ash (3.5\%) [3].

Bottom ash of coal power plants secondary using in construction is the most effective solution to this problem. Therefore, the possibility of using bottom ash of the largest Kuzbass coal power plants as raw for the production of building materials production was considered.

\section{Materials and methods}

The bottom ash of Kemerovo district coal power plant, Tom-Usinskaya district coal power plant and Belovo district coal power plant was used for the experiment. Samples were taken at several characteristic points in the ash dump of each power plant.

Each sample was examined using an inductively coupled mass spectrometer Agilent $7500 \mathrm{cx}$ and an inductively coupled plasma optical emission spectrometer iCAP 7400 Duo. The level of ash activity was evaluated by a basicity index representing the ratio of the basic oxides to the amount of acid oxides contained in sample:

$$
i_{b}=\frac{\mathrm{CaO}+\mathrm{MgO}}{\mathrm{SiO}_{2}+\mathrm{Al}_{2} \mathrm{O}_{3}}
$$

and an activity index representing the of alumina to silica:

$$
i_{a}=\frac{\mathrm{Al}_{2} \mathrm{O}_{3}}{\mathrm{SiO}_{2}}
$$

Granulometric properties were determined for a mixture of all each power plant 
samples. Bulk density was defined as the ratio of ash mass to vessel volume:

$$
\rho_{b}=\frac{m}{V}
$$

Average grain density was determined by a method based on measuring the volume of grains in dry quartz sand:

$$
\rho_{g}=\frac{m_{g}}{V_{s}}
$$

True density was determined by the volume of distilled water displaced by ash from the pycnometer by boiling:

$$
\rho=\frac{\left(m_{1}-m_{2}\right) \rho_{H_{2} O}}{\left(m_{1}-m_{2}-m_{3}-m_{4}\right)}
$$

Determination of the grain size composition was carried out by sieving and weighing the samples on a standard set of sieves.

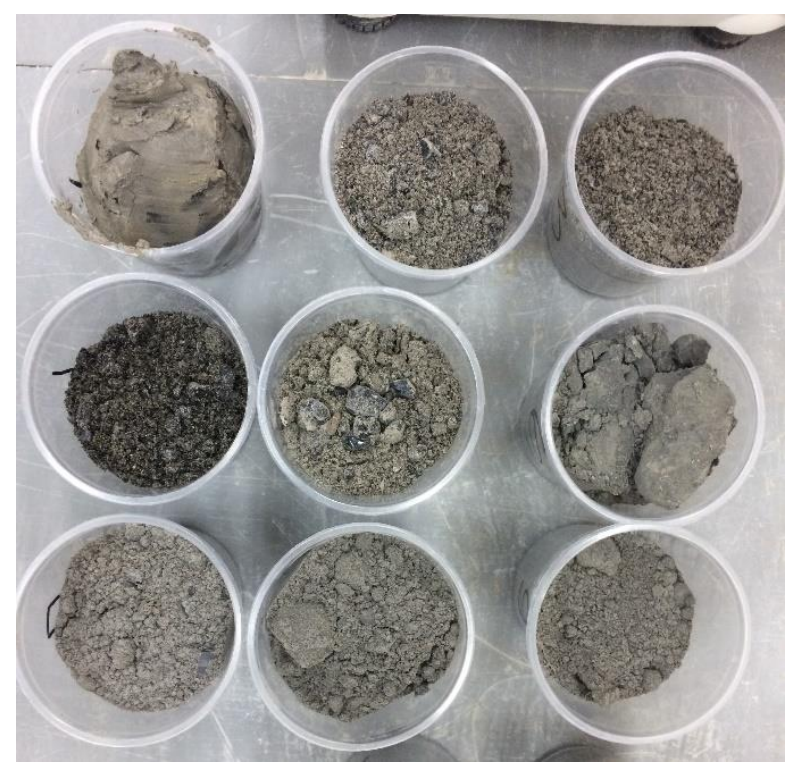

Fig. 2. The bottom ash samples.

\section{Results and Discussion}

Bottom ash of the largest Kuzbass coal power plants contains in relatively low $\mathrm{CaO}$ (3.2$5.1 \%$ ). They consist mainly of transparent acidic ferroaluminosillicate glass $\mathrm{SiO}_{2}+$ $\mathrm{Al}_{2} \mathrm{O}_{3}+\mathrm{Fe}_{2} \mathrm{O}_{3}(80-90 \%)$. The results of chemical analysis are show in table 1 . 
Table 1. Chemical composition of the bottom ash, \%.

\begin{tabular}{|l|c|c|c|c|c|c|c|c|c|}
\hline Component & \multicolumn{3}{|c|}{$\begin{array}{c}\text { Kemerovo district coal } \\
\text { power plant }\end{array}$} & \multicolumn{3}{c|}{$\begin{array}{c}\text { Tom-Usinskaya district } \\
\text { coal power plant }\end{array}$} & \multicolumn{3}{c|}{$\begin{array}{c}\text { Belovo district coal } \\
\text { power plant }\end{array}$} \\
\hline & 1 & 2 & 3 & 4 & 5 & 6 & 7 & 8 & 9 \\
\hline $\mathrm{SiO}_{2}$ & 62.4 & 57.0 & 54.0 & 62.9 & 61.0 & 60.5 & 63.6 & 62.8 & 63.6 \\
\hline $\mathrm{Al}_{2} \mathrm{O}_{3}$ & 19.6 & 20.7 & 18.9 & 16.6 & 17.0 & 17.0 & 17.9 & 17.9 & 14.0 \\
\hline $\mathrm{Fe}_{2} \mathrm{O}_{3}$ & 4.4 & 6.1 & 8.0 & 6.4 & 7.9 & 7.3 & 7.7 & 8.5 & 6.4 \\
\hline $\mathrm{MnO}$ & 0.042 & 0.13 & 0.14 & 0.064 & 0.084 & 0.084 & 0.097 & 0.105 & 0.081 \\
\hline $\mathrm{MgO}$ & 1.18 & 1.1 & 1.12 & 1.41 & 1.91 & 1.75 & 1.31 & 1.43 & 1.61 \\
\hline $\mathrm{CaO}$ & 4.4 & 3.2 & 3.2 & 4.0 & 4.4 & 3.7 & 4.8 & 4.6 & 5.1 \\
\hline $\mathrm{Na}_{2} \mathrm{O}$ & $<0.74$ & $<0.74$ & $<0.74$ & $<1$ & $<1$ & $<1$ & $<1$ & $<1$ & 1.27 \\
\hline $\mathrm{K}_{2} \mathrm{O}$ & 1.9 & 2.5 & 2.3 & 1.24 & 1.23 & 1.05 & 1.05 & 1.9 & 2.0 \\
\hline $\mathrm{TiO}_{2}$ & 0.95 & 0.82 & 0.84 & 1.05 & 0.95 & 1.06 & 0.75 & 0.76 & 0.69 \\
\hline $\mathrm{P}_{2} \mathrm{O}_{5}$ & 0.77 & 0.23 & 0.3 & 0.59 & 0.58 & 0.47 & 0.35 & 0.36 & 0.33 \\
\hline $\mathrm{SiO}_{2}+\mathrm{Al}_{2} \mathrm{O}_{3}+$ & & & & & & & & & \\
$\mathrm{Fe}_{2} \mathrm{O}_{3}$ & 86.4 & 83.8 & 80.9 & 85.9 & 85.9 & 84.8 & 89.2 & 89.2 & 84.0 \\
\hline
\end{tabular}

Basicity index ranges from 0.06 to 0.09 and an activity index ranges from 0.22 to 0.36 (table 2), which means that dump ash does not have independent hydraulic activity.

Table 2. The value of basicity index and activity index of the bottom ash

\begin{tabular}{|c|c|c|c|c|c|c|c|c|c|}
\hline Index & \multicolumn{3}{|c|}{$\begin{array}{c}\text { Kemerovo district coal } \\
\text { power plant }\end{array}$} & \multicolumn{3}{c|}{$\begin{array}{c}\text { Tom-Usinskaya district } \\
\text { coal power plant }\end{array}$} & \multicolumn{3}{c|}{$\begin{array}{c}\text { Belovo district coal } \\
\text { power plant }\end{array}$} \\
\hline & 1 & 2 & 3 & 4 & 5 & 6 & 7 & 8 & 9 \\
\hline $\mathrm{i}_{\mathrm{b}}$ & 0.07 & 0.06 & 0.06 & 0.07 & 0.08 & 0.07 & 0.07 & 0.07 & 0.09 \\
\hline $\mathrm{i}_{\mathrm{a}}$ & 0.31 & 0.36 & 0.35 & 0.26 & 0.28 & 0.28 & 0.28 & 0.29 & 0.22 \\
\hline
\end{tabular}

Bottom ash of the largest Kuzbass coal power plants are characterized by an insignificant spread in density (table 3), while the unit surface area ranges from 1900 to $3714 \mathrm{~cm}^{2} / \mathrm{g}$ [4].

Table 3. Granulometric properties of bottom ash

\begin{tabular}{|c|c|c|c|}
\hline Name of power plant & $\begin{array}{c}\text { Bulk density, } \\
\mathrm{kg} / \mathrm{m}^{3}\end{array}$ & $\begin{array}{l}\text { Average grain } \\
\text { density, } \mathrm{kg} / \mathrm{m}^{3}\end{array}$ & $\begin{array}{c}\text { True density, } \\
\mathrm{kg} / \mathrm{m}^{3}\end{array}$ \\
\hline $\begin{array}{l}\text { Kemerovo district coal } \\
\text { power plant }\end{array}$ & 1473 & 1583 & 2360 \\
\hline $\begin{array}{l}\text { Tom-Usinskaya district } \\
\text { coal power plant }\end{array}$ & 1049 & 1497 & 2300 \\
\hline $\begin{array}{l}\text { Belovo district coal power } \\
\text { plant }\end{array}$ & 1151 & 1636 & 2050 \\
\hline
\end{tabular}

Table 4. Grain size composition of bottom ash

\begin{tabular}{|l|c|c|c|c|c|c|c|c|c|c|}
\hline $\begin{array}{l}\text { Name of } \\
\text { power plant }\end{array}$ & $\mathbf{4 0}$ & $\mathbf{2 0}$ & $\mathbf{1 0}$ & $\mathbf{5}$ & $\mathbf{2 . 5}$ & $\mathbf{1 . 2 5}$ & $\mathbf{0 . 6 3}$ & $\mathbf{0 . 3 1 5}$ & $\mathbf{0 . 1 4}$ & $<\mathbf{0 . 1 4}$ \\
\hline $\begin{array}{l}\text { Kemerovo } \\
\text { district coal } \\
\text { power plant }\end{array}$ & 0 & 2.6 & 16.2 & 34.7 & 58.4 & 64.4 & 72.0 & 78.3 & 95.3 & 101.3 \\
\hline $\begin{array}{l}\text { Tom- } \\
\begin{array}{l}\text { Usinskaya } \\
\text { district coal } \\
\text { power plant }\end{array}\end{array}$ & 0 & 3.5 & 5.0 & 8.6 & 14.6 & 18.6 & 26.1 & 36.6 & 63.6 & 97.8 \\
\hline $\begin{array}{l}\text { Belovo district } \\
\text { coal power } \\
\text { plant }\end{array}$ & 0 & 2.2 & 5.1 & 9.6 & 28.3 & 35.3 & 46.5 & 50.0 & 57.0 & 96.5 \\
\hline
\end{tabular}


As can be seen from the table 4, the bottom ash of Belovo district coal power plant contains only $9.6 \%$ of fractions of $5-20 \mathrm{~mm}$, particles equal to or less than $0.14 \mathrm{~mm}$ are $46.5 \%$. Ash within the fractions of $0.315-5 \mathrm{~mm}$ fits into the optimal zone of the grain size composition of the sands, the excess of fraction $<0.14$ in it can be considered as a micro filler. According to the grain size composition, this aggregate can be classified as sands intended for lightweight concrete.

The bottom ash of Kemerovo district coal power plant contains $34.7 \%$ of coarse fractions (more than $5 \mathrm{~mm}$ ), the presence in its composition of particles that have passed through a $0.14 \mathrm{~mm}$ sieve is $6 \%$. This aggregate does not meet the grain size requirements for porous sands and can be considered only as a mixture of fine and large grains.

The bottom ash of Tom-Usinskaya district coal power plant contains almost $50 \%$ of dusty fractions, and the volume of particles larger than $1.25 \mathrm{~mm}$ is only $18.6 \%$. This fine aggregate can be considered as a mixture of dusty ash and fine sand.

\section{Conclusion}

The results of the research show that the bottom ash of Belovo district coal power plant and Tom-Usinskaya district coal power plant can be used as a filler for various types of lightweight concrete. The bottom ash of Kemerovo district coal power plant should be considered as a possible aggregate for heavy concrete.

Thus, bottom ash of the largest Kuzbass coal power plants can be used as raw for the building materials production.

\section{References}

1. V.J. Putilov, Ecology Energy, (MEI Publishing, Moscow, 2003)

2. P.G.S. Gimhan, J.P.B. Disanayaka, and M.C.M. Nasvi, 2018. Geotechnical Engineering Properties of Fly Ash and Bottom Ash, Use as Civil Engineering Construction Material. Engineer, Journal of the Institution of Engineers, Sri Lanka, 51(1)

3. A. Kargin, V. Baev, N. Mashkin, and A Uglyanica, Fly ash: Perspective resource for geo-polymer materials production, AIP Conference Proceedings 1698, 070009 (2016)

4. Aleksey Kargin, Vladimir Baev, and Nikolay Mashkin, "Fly-ash geo-polymer foamed concrete", AIP Conference Proceedings 1800, 020005 (2017)

5. C. Satish, Waste Materials Used in Concrete Manufacturing (Noyes Publications, Westwood, New Jersey, 1997)

6. N. Gilyazidinova, E. Shabanov, X. Liu, E3S Web of Conferences IVth International Innovative Mining Symposium, 01039 (2019)

7. N.V. Gilyazidinova, N.Yu. Rudkovskaya, T.N. Santalova, The 8th Russian-Chinese Symposium Coal In The 21st Century: Mining, Processing And Safety, 62 (2016)

8. N.V. Gilyazidinova, V.B. Duvarov, A.S. Mamytov, E3S Web of Conferences Vth International Innovative Mining Symposium, 01012 (2020) 